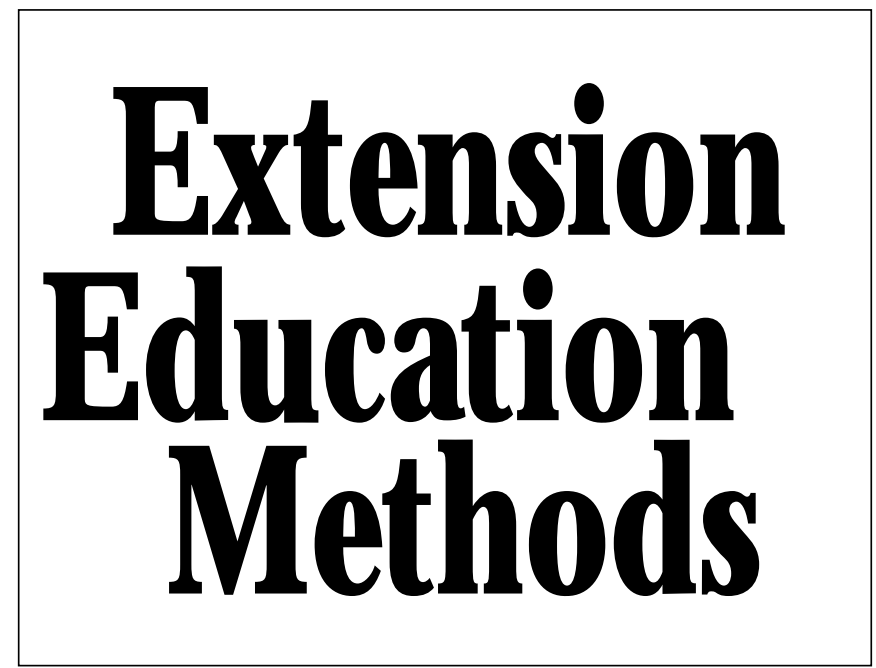

\section{Edina Goes Green Part I: A Model for Low-input Lawn Care Community Education}

\author{
Perrin J. Carpenter and \\ $\mathrm{M}$ ary $\mathrm{H}$ ockenberry $\mathrm{M}$ eyer
}

\begin{abstract}
ADDITIONAL INDEX wORDS. sustainable turfgrass, lawn ordinances, teaching methods, demonstration sites, community education, lawn care
\end{abstract}

\begin{abstract}
Summary. A yearlong community education project was conducted in Edina, M inn., to teach residents about lowinput lawn care techniques. Informational articles, a World Wide Web (Web) page, public seminar, and demonstration sites were the four major strategies employed by the project. E ach of these teaching methods had a specific objective for influencing the lawn care knowledge and practices of E dina residents. Feedback from surveys at the completion of the project showed that printed articles had the highest familiarity. Based on these results, recommendations are given for other communities to implement low-input lawn care education programs.
\end{abstract}

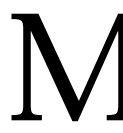

any municipalities have ordinances concerning lawn care; height of grass, setbacks, and even the type of plants permitted (Balbach and Balbach, 1998). Increasingly, these ordinances have been challenged, as homeowners become concerned about the environmental effects of a traditional lawn (D iekelman and Bruner, 1978; Gillespie, 1990; H anchek, 1994). Although the numerous benefits of turf have been published (Beard and Green, 1994; Leslie and Knoop, 1989) there remains a perception of inputs, especially pesticides and fertilizers, as having a negative environmental impact.

In an effort to teach environmentally responsible and low-

D epartment of H orticultural Science, U niversity of M innesota, St Paul, 55108.

$M$ innesota Experiment Station scientific journal series paper 981210035 . The cost of publishing this paper was defrayed in part by the payment of page charges. U nder postal regulations, this paper therefore must be hereby marked advertisement solely to indicate this fact. input lawn care, community leaders and concerned citizens of Edina, M inn. (a M inneapolis suburb), initiated a community educational program, called Edina Goes Green (EGG).

TheU niversity of $M$ innesotaExtension Service provided information about low-input lawn care and coordinated the EGG program, which operated from M arch 1996 through June 1997. The primary source of information was the U niversity of M innesotaE xtension Servicepublication, LI LaC: Low-Input Lawn Care (M ugaas, 1995). EGG used four educational methods, each with its own goal of affecting the knowledge, attitude, and/ or practices of Edina residents toward the task of lawn care. This article outlines the EGG program and critiques the teaching methods used. Concluding information offers recommendations to other communities interested in low-input lawn care.

\section{Background and resources}

Before the start of EGG, E dina City Council had voted to changethe way the city managed the turf in itspublic parks. In February 1995 a new turf management plan was adopted that would eliminate or severely reduce the use of lawn chemicals on public areas (E dinaPark and Recreation D epartment, 1995). R esidents who had supported this change then began to think of ways to educate the community as a whole about low-input lawn care. It was thought that a greater understanding of this approach would make for wider acceptance of the city's plan and could also lead to reduced use of lawn chemicals on private property.

In EGG, resourcesavailable for the program were closely linked with community support. EGG was unique in that it was initiated by Edina residents. M embers of the Edina L eague of Women Voters, the Edina Community $\mathrm{H}$ ealth Services Advisory Committee (ECH SAC), and other concerned citizens were instrumental in forming a partnership between the City of Edina and U niversity of M innesota Extension Service, and in applying for funding for the program. TheE GG committee applied for and received a Sustainable U rban Landscape Education Program grant from the $U$ niversity of M innesota. Thus, the major material and financial resources for the project came about as a direct result of community involvement and support.

Key factors in a successful community educational program include identifying financial and material resources available, gathering support within the community, identifying clear and measurable objectives, and planning a schedule and strategies to meet those objectives using the available resources.

Thegrant provided funding to hirea project coordinator for one year. Thisposition involved organizing, planning, and implementing the educational campaign. The goal was to make use of the available resources to develop an educational program that would reach a wide audience at a variety of levels within the community. Extension programs in other areas have shown this to be a successful approach to community education (Aveni and $\mathrm{H}$ artung, 1997).

Thefour educational techniquesand objectivesareevaluated below. At the start and end of the program, surveys were distributed to 800 random households in Edina asking questions about lawn care knowledge and practices. The final survey also asked questions about the respondent's familiarity with the EGG program.

\section{Published articles}

Seven articles were published concerning the project 
Table 1. Publications about E dina G oes G reen (E G G ) educational program, M arch 1996 to J une 1997.

\begin{tabular}{lll}
\hline Publication & Date & Title \\
\hline A boutTown & Summer 1996 & A year-round guide to home lawn care, part 1 \\
A boutT own & Fall 1996 & A year-round guide to home lawn care, part 2 \\
A boutTown & Fall 1996 & Edina goes green \\
SunC urrent & 21 Aug. 1996 & 'U' program helps Edina 'go green' \\
SunC urrent & 14 M ay 1997 & Answers to common questions on lawn fertilizers \\
SunC urrent & 21 M ay 1997 & Knock out weeds not environment \\
SunC urrent & 28 M ay 1997 & Tips for your lawn to make it in the shade \\
\hline
\end{tabular}

(T able1). A boutT own, aquarterly magazinepublished byE dina's Park and Recreation Department, is distributed free to Edina residents. Thefreeweekly SunC urrent newspaper also ran articles on EGG. M embers of the EGG committee were instrumental in contacting the newspaper and supplying the articles.

The objective of publishing informational articles was to educate $\mathrm{E}$ dina residents as a whole. The articles were distributed to all residents and were purely informational, requiring no effort on the part of the recipient other than choosing whether or not to read them.

Survey results indicated that these articles were the most widely used educational tools of EGG's program. As Table 2 shows, of thoserespondentswho knew about theEGG program, morewere familiar with the A boutT own and SunC urrent articles than any other aspect of the program. H omeowner surveys conducted in other communities have asked respondents to rate their preferred methodsfor receiving information and determined that printed materials, either from mailings or newspapers, are consistently preferred over other teaching methods ( $L$ ajeunesseet al., 1997; M innesota Center for Survey Research, 1995).

\section{Web site}

A Web site was posted in February 1997 with the objective of providing up-to-date information about the program. Thesite contained introductory information, copies of the published articles, demonstration site addresses, and results from the first survey. The Web address was advertised at the end of the SunC urrent newspaper articles.

Like the published articles, theW eb site was primarily an informational teaching tool. It did, however, require more effort on the part of those using it than did the A boutT own or SunC urrent articles. The Web information required a computer, Internet access and the desire to seek information independently. The EGG's site was not posted until halfway through the program and was not actively advertised until much later, thus making it relatively ineffective in reaching residents. O nly $\approx 2 \%$ of residents were familiar with the Web page by the end of the program (Table 2 ).

This result should not rule out the use of Web pages in community education projects. With more advertising and planning, aWeb pagecan bearelatively easy way to makeavailablelarge amounts of information (Peet, 1998). It also has the capacity for expansion through e-mail to become a mode of communication between participants and project organizers. For projects with limited financial resources, posting information on theW eb can be quite cost effective. EGG's site was posted on the I nternet at no cost asalink from the Department of $\mathrm{H}$ orticultural Science'sWeb site at the U niversity of M innesota.

\section{Public seminar}

A free public seminar, hosted and funded by E dina Park and Recreation D epartment, in M arch 1996 wastitled "L awn Care for the 90's: A Pinch N ot a Pound" and featured two speakers. The seminar opened with information from a waste prevention specialist from the $\mathrm{M}$ innesota $\mathrm{O}$ ffice of Environmental Assistance. The primary speaker was a turf specialist and consultant hired by the City of Edina to assist in implementing their new turf management plan.

The objectives of the seminar were to provide professional information on lawn care and to givethoseattending an opportunity to ask questions pertaining to their own lawns. About 100 people attended and audience response to the program was overwhelmingly positive. This event required much more effort on the part of the participants than did the published articles or the web site. It is likely that only those residents al ready interested in lawn care would be motivated to attend. In that respect, only a small number, $\approx 1 \%$ of residents were familiar with this event (T able 2 ).

\section{Demonstration sites}

Thelastmajor educational tool used wasademonstration site project. This was a yearlong program that paired $12 \mathrm{M}$ aster Gardeners (M Gs) with 19 homeowners, who agreed to use their lawns as demonstration sites. M Gs are volunteers trained by extension to teach horticulture in the community (M eyer, 1997).

The objectives of these demonstration sites were to 1 ) provide an individualized learning experience for the homeowners, and 2) provide public examples of low-input lawn care, and 3) eval uatehomelawnsasdemonstration sites. For thehomeowners, this was the most intensive teaching method EGG used. It required ayearlong commitment and thedesireto learn about and hopefully implement changes in their lawn care practices.

The project was promoted and participants' addresses published in the A boutTown and SunCurrent publications and on EGG's web site. However, only $1.1 \%$ of Edina residents werefamiliar with this educational tool by the end of the program. For completeinformation on the demonstration sites, see Carpenter and M eyer, 1999a.

\section{Other educational tools}

O ther educational methods, also had some influence on the program. EGG hosted an informational booth at an Edina $\mathrm{C}$ ity $\mathrm{H}$ all $\mathrm{O}$ pen $\mathrm{H}$ ouse held at in February 1997. A member of theE GG committeetended the booth, and EGG flierswere distributed. As indicated in Table 2, this was not a highly influential event. I t was, however, an opportunity for members of the EG G committee to takeamoreactive rolein promoting the program. The committee member handing out flierscame away from the event with the sense that hehad madea valuable contribution to the program. Such a sense of satisfaction, that each participant has a significant role to play in the program, may be essential for ongoing success. 
$T$ able 2. R esponses to the survey after the $E$ dina $G$ oes $G$ reen (E G G) educational campaign rating familiarity with the program and each educational component.

\begin{tabular}{lr} 
Survey & Frequen \\
question & (\%) \\
\hline Familiarity with EGG program & 6.0 \\
Very familiar & 24.2 \\
Somewhat familiar & 29.0 \\
Vaguely familiar & 39.9 \\
N ot at all familiar & \\
Which of these sources are you or anyone in your household familiar with, whether or not you have used the & 31.3 \\
source personally? (Please circle all that apply) & 34.5 \\
Articles in Edina's A boutT own magazine & 1.9 \\
Articles in Edina's SunCurrent newspaper & 1.1 \\
EGG's Web page & 1.1 \\
Public seminar & 8.4 \\
Demonstration sites & 1.5 \\
Word of mouth & 3.9 \\
City H all open house & 47.6 \\
Other sources (write-in response) & \\
N ot familiar with the program &
\end{tabular}

Word-of-mouth had some influence and most likely was a result of the high degree of community-member participation in the project (Table 2). Members of the League of Women Voters, ECHSAC, Edina's Park and Recreation D epartment, and the demonstration site participants were all involved in promoting the program and motivating others through interactions with friends and neighbors. This is one indication of the important role that community support for a project can play in its success.

The final survey of the project found that $30.2 \%$ of respondents were somewhat or very familiar with EGG. The effect these articleshad on E dinaresidents' lawn carepracticesand knowledge is addressed elsewhere (C arpenter and M eyer, 1999b).

\section{Recommendations for other communities}

To implement a program of reduced inputs and environmentally responsible lawn care we offer the following recommendations:

IDENTIFY RESOURCES AVAILABLE WITHIN THE COMMUNITY. L ocal newspapersorotherpublications, communityaction groups, garden clubs, and city government organizations can provide support, publicity, and resources for educational programs.

IDENTIFY FINANCIAL RESOURCES. G rants and funding sources from community organizationscan help with the cost of labor, mailings, printing, supplying and distributing brochures and fact sheets, and other expenses. The amount of funding available will directly affect the types of educational programs that can be offered.

InVOLVE LOCAL CITIZENS IN AN ACtive Role. O ffer residents the opportunity to help organize and implement programs. Such involvement can increase the program's popularity and may encourage continuation of the program beyond the established time frame.

Outline measurable goals and objectives. For each educational program, determinethedesired outcome, whether a change in participant'sknowledge or practices. U se periodic feedback from the participantsto determine if the project ison track, and bewilling to change programsthat are not working. If a seminar is held, obtain participants' addresses so a follow up survey can beconducted to evaluate program effectiveness.
Offer a mide variety of opportunities mith varying LEVELS OF COMMITMENT. Those with lower requirements, such as newspaper articles, will be able to reach more people, but those with higher requirements can have more influence for changing the lawn care practices.

Use DEMONSTRATION SITES MTTH MDELY PUBLICIZED OPEN HOusEs. I dentify the sites with informational signs, and have homeowners and $\mathrm{M} \mathrm{G}$ on hand to answer questionsfrom visitors.

Continue the PROgram for at least 2 years. Broccolo (1989) emphasizes educating the public takes time and commitment. Repetition is important, especially where low involvement is concerned. A longer program will also facilitate measuring lasting change in the community.

\section{Literature cited}

Aveni, M .T . and L.F. H artung. 1997. The water-wise gardener: An extension agent's guide to planning and delivering residential watershed water-quality programs. Va. C oop. Ext. Va. Tech, Blacksburg.

Balbach, H.E. and M.K. Balbach. 1998. Regulatory oversight of natural and alternative landscapes. H ortScience 33(3):450 (abstr.)

Beard, J.B. and R.L. Green. 1994. The role of turfgrasses in environmental protection and their benefits to humans. J. Environ. Qual. 23:452-460.

Broccolo, L. 1989. An award-winning management plan, p. 597602. In: A.R. Leslie (ed.). Integrated pest management for turf and ornamentals, CRC Press, Boca Raton, Fla.

Carpenter, P.J . and M.H . M eyer. 1999a. Edina goes green part II: U sing home lawns as demonstration sites to teach low-input lawn care. H ortT echnology 9(3):489-491.

Carpenter, P.J . and M.H . M eyer. 1999b. Edina goes green Part III: A survey of consumer lawn careknowledge and practices. $\mathrm{H}$ ortT echnology 9(3):491-494.

Diekelmann, J. and C. Bruner. 1978. An introduction to naturalized landscapes: A guideto M adison's" natural lawn" ordinance. D ept. of Planning and D evelopment, M adison, Wis.

Edina Park and Recreation D epartment. 1995. Turf management plan. City of Edina, M inn. 
Gillespie, A.P. 1990. H omemeadows confronting weed ordinances. Wildflower 3(4):12-18.

H anchek, A.M. 1994. In the eye of the beholder: The case of the M innetonka lawn ordinance. H ortT echnology 4(3):304-310.

Lajeunesse, S.E., G.D . Johnson, and J.S. Jacobsen. 1997. A homeowner survey: 0 utdoor pest management practices, water quality awareness, and preferred learning methods. J. N atural Resources L ife Sci. Educ. 26(1):43-48.

Leslie, A.R. and W. Knoop. 1989. Societal benefits of conservation oriented management of turfgrass in home lawns, p. 93-96. In: A.R. Leslieand R.L. M etcalf (eds.). Integrated pest management for turfgrass and ornamentals. U .S. EPA O ffice Pest. Progr., Wash., D.C.

M eyer, M .H . 1997. M aster gardener projects: M aking connections. H ortT echnology 7(4):339-344.

M innesota Center for Survey Research. 1995. Lawn care survey and focus groups: Results and technical report. Tech. Rpt. 95-25. U niv. Minn., M inneapolis.

M ugaas, R. 1995. LILaC: Low-input lawn care. M inn. Ext. Serv. M etro Cluster, U niv. M inn.

Peet, M . 1998. Developing, converting and maintaining information-rich resources on the World Wide Web. HortT echnology 8(3):307-312. 